\title{
Hemşirelerde Yöneticiye Güvenin Kişi-Örgüt Uyumuna Etkisi
}

\author{
The Effect of Trust in the Nurses on Person-Organization Fit
}

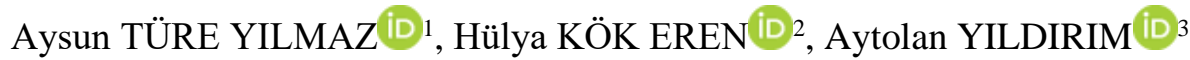

Öz

Kesitsel nitelikte olan bu çalışma hemşirelerde yöneticiye duyulan güvenin kişi-örgüt uyumu üzerine etkisini araştırmak amacıyla yapılmıştır. Örneklem seçimine gidilmeden çalışmaya katılmayı kabul eden hemşirelerden veriler toplanmış ve toplamda örneklem sayısı $(\mathrm{n}=402)$ olmuştur. Veri Toplama Araçları olarak "Kişisel Bilgi Formu", "Yöneticiye Güven Ölçeği” ve "Kişi - Örgüt Uyumu Ölçeği” kullanılmıştır. Verilerin analizinde Mann-Whitney U, Kruskal-Wallis H, ANOVA testi ve Spearman korelasyon kullanılmıştır. Çalışmaya katılan hemşirelerin çalışma yılı ortalaması, $7.47 \pm 6.54$ (min:1.0, maks:26.0) yıl olup, \%49.0'unun ( $\mathrm{n}=197), 1-5$ yıl arasında çalıştığ çalışıı̆̆ klinikten memnun, \%37.6'sı (n=151) kısmen memnundur. Hemşirelerin \%34.3'ü $(n=138)$ çalıştığı klinikten ayrılmayı düşünmektedir. Hemşirelerin, Yöneticiye Güven Ölçeği ortalama puanı (Ort. = 18.33, $S=4.47$ ), Kişi Örgüt Uyumu Ölçeği ortalama puanı (Ort. $=14.02, S=3.86$ )'dir. Çalışmamızda yöneticiye duyulan güven ile kişi örgüt uyumu arasında anlamlı ilişki bulunmuştur.

Anahtar Kelimeler: Hemşire, yöneticiye güven, örgüt uyumu

Makale Türü: Araştırma

\begin{abstract}
This cross-sectional study was conducted to investigate the effect of trust in manager on personorganization compliance in nurses. Data were collected from the nurses who agreed to participate in the study and the total number of samples $(\mathrm{n}=402)$ was taken. "Personal Information Form", "Supervisor Trust Scale" and "Person-Organization Fit Scale" were used as data collection tools. Mann-Whitney U, KruskalWallis H, ANOVA test and Spearman correlation were used for data analysis. Average of study year of nurses was $7.47 \pm 6.54$ (mim: 1.0 , max: 26.0$)$, and $49.0 \%(n=197)$ were found to work between 1-5 years. $53.2 \%(n=214)$ of the nurses were satisfied with the clinic and $37.6 \%(n=151)$ were partially satisfied. $34.3 \%(n=138)$ of the nurses were considering leaving the clinic. The average score of the nurses and the Manager Trust Scale was $(M=18.33, S D=4.47)$, and the Person- Organization Fit was $(M=14.02, S D=$ 3.86) In our study, a significant relationship was found between trust in the manager and person organization compliance.
\end{abstract}

Keywords: Nurse, supervisor trust, organization fit

Paper Type: Research

\footnotetext{
${ }^{1}$ Eskişehir Osmangazi Üniversitesi, Sağlık Bilimleri Fakültesi, ature@ ogu.edu.tr.

22Eskişehir Osmangazi Üniversitesi, Sağlık Bilimleri Fakültesi, hulyakok2911@ gmail.com.

${ }^{3}$ İstanbul Üniversitesi, Florence Nightingale Hemşirelik Fakültesi, aytolany@ mynet.com.
}

Atıf için (to cite): Türe Yılmaz, A., Kök Eren H. Ve Yıldırım, A. (2019). Hemşirelerde Yöneticiye Güvenin Kişi Örgüt Uyumuna Etkisi. Afyon Kocatepe Üniversitesi Sosyal Bilimler Dergisi, 21(4), 1205-1215. 


\section{Giriş}

Sağlık kurumları arasındaki rekabetin gün geçtikçe artması, örgütlerin insan kaynaklarını daha iyi yönetme isteğine yol açmıştır. İyi yetişmiş insan kaynağını bulmak, örgüte çekebilmek ve işe alınan bireyin örgüt değerleri ile uyum sağlaması, yöneticisi ile iyi etkileşim kurması bireyin örgütteki geleceğini de belirlemektedir. Kurumlar her zaman kendilerine uygun elemanlar seçmek ve seçtikleri elemanları işe aldıktan sonra da geliştirmek isterler. Mesleğin ve işin gerektirdiği yeteneğe sahip bireyleri örgüte çekmek, işe başlatmak ve geliştirmek insan kaynaklarının en önemli işlerinden biri olmuştur (Arbak ve Yeşilada, 2003). Bu araştırma hemşirelerde yöneticiye duyulan güvenin kişi-örgüt uyumu üzerine etkisini araştırmıştır.

\section{1. Örgüt Uyumu}

Örgütün değerleri ile kişinin değerleri arasındaki uyum arttıkça kişi örgüte daha da yaklaşır. Örgütte kişinin yöneticisi, kişi ile örgüt arasında önemli bir rol almaktadır. Günümüz koşullarında üst yönetimde alınan kararların örgüt genelinde etkin bir şekilde gerçekleşebilmesi için öne çıkan görüş, yöneticinin lider olması yaklaşımıdır (Gerstner ve Day, 1997).

Örgütlerin başarısı örgütsel davranışı oluşturan; güven, adalet, bağlılık, tatmin, motivasyon gibi psikolojik faktörlere dayanmaktadır. Güven, bir kişinin diğer bir kişinin sözlerine ve davranışlarına kuşku duymadan inanması, bağlanması, davranışlarına iyi niyet atfetmesi, başka bir kişinin davranışlarından ve kararlarından emin olması ve bunlara göre hareket etme istekliliğidir (Cook ve Wall, 1980; McAllister, 1995). Güven bireyin davranışlarını anlamlandırmada anahtar değişkendir (Driscoll, 1978). Güvenen kişi, karşı tarafın olumlu davranışlar sergileyeceği düşüncesindedir ve onu kontrol etmeyi düşünmeksizin eylemlerine karş1 savunmasız kalmaya gönüllü olmaktadır (Mayer ve ark., 1995).

Örgütsel yapı içerisinde kişiler arasındaki güven, bilişsel ve duygusal olmak üzere iki ayrı boyutta incelenmektedir. Bilişsel güven, yöneticilerin karakteristik özelliklerinin çalışanların tutum ve davranışları üzerindeki etkisini, bir kişinin güvenilirliği, doğruluğu, dürüstlüğü ve bağl1lığına ilişkin diğer kişilerin düşünsel modellerini ifade eder. Duygusal güven ise, yönetici ile çalışan arasındaki kurulan ilişkide, kişilere gösterilen özen ve ilgi sonucunda gelişen, duygusal bağın yansıttığı güçlü ve özel bir ilişkiyi anlatır (Arslantaş ve Dursun, 2008). Güvenin örgütsel başarı için önemli olduğu, ancak hemen sağlanamadığı, uzun ve özverili çabalar gerektirdiği sonucuna varılmıştır (Demircan ve Ceylan, 2003).

\section{Yöneticiye Güven}

Çalışma ortamındaki güven kişilerin birbirlerine duygu ve düşüncelerini açıkça dile getirmelerini, iş doyumunu, iş performansını, örgütsel bağlılığ 1 ve işbirliğini artırdığı, örgütsel vatandaşlığı sağladığı, işten ayrılmaları azalttığı görülmektedir (Demircan ve Ceylan, 2003: Arı, 2003; Çokluk Bökeoğlu ve Yılmaz, 2008; Thomas ve ark., 2009; Yeşiltaş ve Keleş, 2009). Yöneticinin çalışanlara güven verebilmesi için sözleriyle yapmış olduğu davranışlar birbiriyle tutarlı olmalı, çalışanlarıyla açık iletişim kurmalı, dürüst olmalı, çalışanlara karşı yardımsever olmalı ve görevlerini başarıyla yerine getirebilecek yeterli donanıma sahip olmalıdır (Mishra, 1996).

Yöneticiye duyulan güven ise; bireyin yöneticisine olan güven hissi, yöneticinin etik ve adalet uygulamalarındaki tutumları ile şekillenmektedir (Koç ve Yazıcıoğlu, 2011). Çalışanın yöneticisine şüphe duymaması ve ona her koşulda güvenmesi lideri ile arasındaki ilişkinin kalitesini arttırır (Arslantaş ve Pekdemir, 2007). Çalışan uyumunun sağlanmasında çok sayıda faktör rol almasına rağmen yakın dönemde en çok göze çarpan faktörlerden birisi güvendir. Pek çok davranışının öncülü olan bu faktörler çoğu çalışanın beklentisi olan önemli örgütsel değişkenlerdir (Ashforth ve ark., 2007; Bauer ve ark., 2007). 


\section{Yöneticiye Güven ve Örgüt Uyumu}

Kişi-örgüt uyumu, örgüt çalışanlarının değer yargıları ile örgütün değer sistemi arasındaki bağlantı olarak tanımlanır. Örgüt kültürü, geleceği için çok önemli olan insan kaynakları politikasını belirlemesinde ve iş ile doğru insanı buluşturabilmesinde çok önemli rol oynamaktadır (Yahyagil, 2005).Kristof (1996)'a göre kişi örgüt uyumu, karşıllıklı beklentilerin karşılandığı, tarafların benzer özelliklere sahip oldukları veya her iki durumunda mevcut olduğu şartlarda ortaya çıkan örgüt ile çalışan arasındaki uyumdur. Kişi-örgüt uyumu, kişi çevre uyumunun bir alt boyutudur (Kristof, 1996). Lewin (1935)'in davranışları, kişi ve çevrenin bir fonksiyonu olarak gören klasik formülüne dayanan kişi-çevre uyumu, genel anlamda kişi ile örgüt arasındaki ahenk, benzerlik ve uyum olarak tanımlanmaktadır (Levin, 1935). Murray'in ihtiyaçbaskı modeli Murray (1951) ve davranışları kişi ve çevresinin bir fonksiyonu olarak açıklayan Lewin'in (1935) alan teorisi kişi çevre uyumuna dayanak sağlayan teorik çalışmalardır. Kişi çevre uyumu kapsamı içerisinde en yaygın olan kavramlar ise; kişi- iş uyumu ve kişi- örgüt uyumudur. Kişi-iş uyumu; kişisel bilgi, beceri ve yeteneklerin iş ile uyumu olarak, kişi-örgüt uyumu ise kişisel ve örgütsel değer, hedef ve ihtiyaçların uyumu olarak tanımlanmaktadır (Turunç ve Çelik, 2012).

Kristof (1996)'un yaptı̆̆ nitel çalışmada kişi-örgüt uyumunu sağlamanın; insanların ve örgütün temel özelliklerindeki benzerliklerin belirlenmesi, örgüt liderleri ile çalışanların hedeflerinin uyumunun sağlaması, kişisel tercihlerin örgüt yapısı ve sistemi ile uyumlu hale getirilmesi ve kişilerin kişiliği ile örgüt iklimi arasında uyum sağlanması olmak üzere dört farklı yolu olduğunu ifade edilmiştir (Turunç ve Çelik, 2012). Çalışanın yöneticisine şüphe duymaması ve ona güvenmesi lideri ile arasındaki ilişkinin kalitesini arttırır (Arslantaş ve Pekdemir, 2007).

Çalışanların yöneticileri ve çalıştığı örgüt ile uyumlu olması örgütsel verimliliğin önemli faktörlerinden biridir. Gününün çok büyük kısmını çalıştığ 1 örgütte geçiren çalışan yöneticisine ve çalıştığı örgüte güvenmek ister. Lideri ve çalıştığı örgütü ile güven ilişkisi kuran çalışan kendisinden beklenenin üzerinde çalışarak verimliliğini arttırır.

\section{Araştırmanın Amacı ve Önemi}

Sağlik hizmetlerinin daha verimli ve etkin bir şekilde sunulabilmesi, hemşirelerin iş doyumu, performans ve örgütsel bağlılıklarının artırılması için sağlık çalışanlarının yöneticilerine, kurumlarına ve çalışma arkadaşlarına karşı güven duymaları gerekmektedir. Yönetici hemşirelerin çalışanların sorunları ile yeterince ilgilenmemesi, çalışanlara karşı katı bir tutum sergilemeleri, çalışma arkadaşları ile ilişkilerin kötü olması, örgütsel güveninin azalmasına, devir hızının artmasına, iş doyumunun ve performansının düşmesine ve hasta bakım kalitesinde azalma gibi istenmeyen sonuçlara neden olmaktadır (Altuntaş, 2008). Bu araştırma hemşirelerde yöneticiye duyulan güvenin kişi-örgüt uyumu üzerine etkisini araştırmak amacıyla yapılmıştır.

\section{Araştırmanın Yöntemi}

Kesitsel tipte olan bu araştırmanın evrenini Eskişehir il merkezinde bulunan bir üniversite hastanesinde çalışan hemşireler $(\mathrm{N}=560)$ oluşturmaktadır. Örneklem seçimine gidilmeden çalışmaya katılmayı kabul eden hemşirelerden veriler toplanmış ve toplamda örneklem sayısı $(n=402)$ olmuştur. Veri toplama aracı olarak "Kişisel Bilgi Formu" ve " Yöneticiye Güven Ölçeği" ve "Kişi Örgüt Uyumu Ölçeği " kullanılmıştır.

Kişisel Bilgi Formu: Araştırma kapsamına alınan hemşirelerin yaş, medeni durum, cinsiyet, eğitim durumu, çalıştığ y yl, çalıştı̆̆ klinik, çalıştığı klinikten memnun durumu gibi sosyodemografik ve çalışma yaşamına ait özellikleri içeren 9 sorudan oluşmaktadır.

Yöneticiye Güven Ölçeği: İşletmelerde algılanan güven düzeyini belirlemek üzere Jarvenpaa ve arkadaşları (1998) tarafından geliştirilen ölçeğin, Furumo (2009)'un çalışmasında kullanılan şeklinin Türkçe geçerlilik ve güvenirliği Akkoç ve arkadaşları (2012) tarafından yapılmıştır. Yapılan doğrulayıcı faktör analizi sonucunda ölçeğin tek faktörlü yapısına uyum sağladığı ve 
faktör yüklerinin 0,46 ile 0,80 arasında olduğu tespit edilmiştir. Yapılan güvenirlik analizi sonucunda ölçeğin toplam Cronbach alfa güvenirlik katsayısı 0,85 olarak bulunmuştur. Ölçekte cevaplar 5'li likert ölçeği ile alınmıştır (1=Kesinlikle katılmıyorum, 5=Kesinlikle katılıyorum). Bizim çalışmamızda ise Cronbach alfa güvenirlik katsayısı 0,89 olarak tespit edilmiştir. Ölçekte cevaplar 5'li likert ölçeği ile alınmıştır (1=Kesinlikle katılmıyorum, 5=Kesinlikle katılıyorum).

Kişi - Örgüt Uyumu Ölçeği: İşletmelerde kişi örgüt uyumu düzeyini belirlemek üzere Netemeyer ve arkadaşları (1997) tarafindan geliştirilmiştir. Vilela ve ark. (2008) çalışmasında kullanılan şeklinin Türkçe geçerlilik ve güvenirliği Akkoç ve arkadaşları (2012) tarafından yapılmıştır. Ölçekte cevaplar 5'li likert ölçeği ile alınmıştır (1=Kesinlikle katılmıyorum, 5=Kesinlikle katılıyorum). Yapılan doğrulayıcı faktör analizi sonucunda ölçeğin tek faktörlü yapısına uyum sağladığı ve faktör yüklerinin 0,71 ile 0,85 arasında olduğu tespit edilmiştir. Yapılan güvenirlik analizi sonucunda ölçeğin toplam Cronbach alfa güvenirlik katsayısı 0,81 olarak bulunmuştur. Bizim çalı̧̧mamızda ise Cronbach alfa güvenirlik katsayısı 0,924 olarak tespit edilmiştir.

Çalışmayı uygulamadan önce İstanbul Medipol Üniversitesi'nden 10840098-604.01.01E.485 sayılı ve 04/01/2018 tarihli etik kurul izni daha sonra ve kurum izni alınmıştır. Uygulama sırasında öncelikle hemşirelere çalışmanın amacı, çalışmaya katılmalarının gönüllülük ilkesine dayalı olduğu ve çalışma sonuçlarının sadece bilimsel amaçlarla kullanılacağı konusunda bilgi verilmiştir. Ardından araştırmaya katılmaya gönüllü olan hemşirelere veri toplama araçları uygulanmıştır. Verilerin girilmesi ve değerlendirilmesi SPSS-version21.0 programı ile yapılmıştır. Bulguların yorumlanmasında frekans tabloları ve tanımlayıcı istatistikler kullanılmıştır. Normal dağılıma uygun olmayan ölçüm değerleri için parametrik olmayan yöntemler kullanılmıştır. Parametrik olmayan yöntemlere uygun şekilde, iki bağımsız grubun ölçüm değerleri ile karşılaştırılmasında "Mann-Whitney U" test (Z-tablo değeri), bağımsız üç veya daha fazla grubun ölçüm değerleri ile karşılaştırılmasında "Kruskal-Wallis $H$ " test $\left(\chi^{2}\right.$-tablo değeri) yöntemi kullanılmıştır. Üç veya daha fazla grup için anlamlı fark çıkan değişkenlerin ikili karşılaştırmaları için Bonferroni düzeltmesi uygulanmıştır. Parametrik olmayan bu yöntemler için gösterim "Median [Min.-Max.]" şeklinde yapılmıştır. Normal dağılıma uygun ölçüm değerleri için parametrik yöntemler kullanılmıştır. Parametrik yöntemlere uygun şekilde, bağımsız üç veya daha fazla grubun ölçüm değerleri ile karşılaştırılmasında "ANOVA" test (F-tablo değeri) yöntemi kullanılmıştır. Parametrik olan bu yöntemler için gösterim "Ortalama \pm Standart Sapma" şeklinde yapılmıştır. İki nicel değişkenden en az birinin normal dağılıma sahip olmaması durumunda bu değişkenler arasındaki ilişkiye "Spearman" korelasyon katsayısı ile bakılmıştır.

\section{Bulgular ve Tartışma}

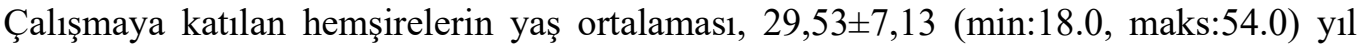
olup, \%48, 5'i (n=195), 26-35 yaş aralığına girmektedir. Hemşirelerin, \%71,6's1 (n=288) kadın, $\%$ 54,5' ü(n=219) evli ve \%50,7'si (n=204) lisans mezunudur. Çalışmaya katılan hemşirelerin

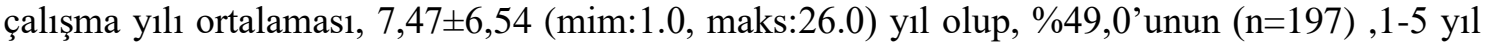
arasında çalıştığ 1 tespit edilmiştir. Hemşirelerin \%39,1'i $(n=197)$ dahiliye kliniğinde, \%26,4'i $(\mathrm{n}=106)$ cerrahi kliniğinde, \%24,6 ' $\mathrm{s} 1(\mathrm{n}=100)$ yoğun bakımlarda çalışmaktadır. Çalışmaya katılan hemşirelerin \%29,1 ‘i ( $\mathrm{n}=117)$ çalıştığı kliniği kendi seçmiştir. Hemşirelerin \%53,2'si ( $\mathrm{n}=214)$ çalıştığ klinikten memnun, \%37,6'sı (n=151) kısmen memnundur. Hemşirelerin \%34,3’ü(n=138) çalıştığı klinikten ayrılmayı düşünmektedir (Tablo 1). Hemşirelerin, Yöneticiye Güven Ölçeği

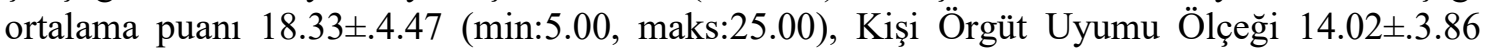
(min:4.00, maks:20.00)' dir.

Hemşirelerin, yaş, cinsiyet, medeni durum, eğitim düzeyi, çalıştığ 1 klinik ve çalıştığ kliniği kendini seçme durumuna göre Yöneticiye Güven Ölçeği puanları acısından anlamlı bir farklılık yoktur( $\mathrm{p}>0,05)$. Hemşirelerin çalışma yılına göre Yöneticiye Güven Ölçeği puanları açısından istatistiksel olarak anlamlı farklılık tespit edilmiştir $\left(\chi^{2}=10,924 ; p=0,004\right)$. Çalışma yılı 1-5 yıl arası olan hemşirelerin Yöneticiye Güven Ölçeği puanları, çalışma yılı 6-10 yıl arası olan hemşirelere göre istatistiksel olarak anlamlı düzeyde daha yüksektir. Hemşirelerin çalıştığ 1 
klinikten memnun olma durumuna göre Yöneticiye Güven Ölçeği puanları açısından istatistiksel olarak anlamlı farklılık tespit edilmiştir $(\mathrm{F}=80,98 ; \mathrm{p}<0.000)$. Çalıştı̆̆ klinikten memnun olan hemşirelerin Yöneticiye Güven Ölçeği puanları, çalıştığ 1 klinikten kısmen memnun olan hemşirelere göre istatistiksel olarak anlamlı düzeyde daha yüksek olduğu bulunmuştur. Çalışmaya katılan hemşirelerin, çalıştığ 1 kliğine değiştirme düşüncesine sahip olma durumuna göre Yöneticiye Güven Ölçeği puanları açısından istatistiksel olarak anlamlı farklılık bulunmuştur. $(\mathrm{Z}=3,803 ; \mathrm{p}<0.000)$. Çalıştığ kliniği değiştirmeyi düşünmeyen hemşirelerin Yöneticiye Güven Ölçeği puanları, çalıştığı kliniği değiştirmeyi düşünen hemşirelere göre istatistiksel olarak anlamlı düzeyde daha yüksektir. (Tablo 1).

Tablo1. Hemşirelerin çalışmayla ilgili özelliklerin, yöneticiye güven ve kişi örgüt uyumu

\begin{tabular}{|c|c|c|c|c|c|c|}
\hline Değişken $(n=402)$ & $\mathbf{n}$ & $\%$ & $\begin{array}{c}\text { Yöneticiye } \\
\text { Güven Ölçeği }\end{array}$ & $\begin{array}{c}\text { İstatistiksel } \\
\text { analiz* }^{*} \\
\text { Olasılık } \\
\end{array}$ & $\begin{array}{c}\text { Örgüt Uyumu } \\
\text { Ölçeği }\end{array}$ & $\begin{array}{c}\text { İstatistiksel } \\
\text { analiz* }^{*} \\
\text { Olasılık } \\
\end{array}$ \\
\hline \multicolumn{7}{|l|}{ Yaş } \\
\hline $18-25^{(\mathrm{a})}$ & 126 & 31,3 & $19,5[5,0-25,0]$ & $\chi^{2}=2,620$ & $16,0[4,0-20,0]$ & $\chi^{2}=7,794$ \\
\hline $26-35^{(b)}$ & 195 & 48,5 & $18,0[7,0-25,0]$ & $\mathrm{p}=0,270$ & $15,0[4,0-20,0]$ & $\mathrm{p}=0,024$ \\
\hline $36-45^{(\mathrm{c})}$ & 81 & 20,1 & $19,0[8,0-25,0]$ & & $16,0[8,0-20,0]$ & {$[b-a, c]$} \\
\hline \multicolumn{7}{|l|}{ Cinsiyet } \\
\hline Kadın & 288 & 71,6 & $19,0[5,0-25,0]$ & $Z=-1,136$ & $15,0[4,0-20,0]$ & $Z=-0,624$ \\
\hline Erkek & 114 & 28,4 & $19,0[5,0-25,0]$ & $\mathrm{p}=0,256$ & $15,0[4,0-20,0]$ & $\mathrm{p}=0,532$ \\
\hline \multicolumn{7}{|l|}{ Medeni Durum } \\
\hline Evli & 219 & 54,5 & $18,0[5,0-25,0]$ & $Z=1,697$ & $15,0[4,0-20,0]$ & $Z=0,628$ \\
\hline Bekar & 183 & 45,5 & $19,0[5,0-25,0]$ & $\mathrm{p}=0,090$ & $15,0[4,0-20,0]$ & $\mathrm{p}=0,530$ \\
\hline \multicolumn{7}{|l|}{ Eğitim Düzeyi } \\
\hline Sağlık Meslek Lisesi(a) & 140 & 34,8 & $19,0[5,0-25,0]$ & & $15,0[4,0-20,0]$ & $\chi^{2}=6,354$ \\
\hline Ön lisans(b) & 58 & 14,4 & $18,0[7,0-25,0]$ & $\chi^{2}=0,731$ & $15,0[5,0-20,0]$ & $\mathrm{p}=0,042$ \\
\hline Lisans $^{(\mathrm{c})}$ & 204 & 50,7 & $19,0[5,0-25,0]$ & $\mathrm{p}=0,694$ & $15,0[4,0-20,0]$ & [a-b] \\
\hline \multicolumn{7}{|l|}{ Çalışma Yılı } \\
\hline $1-5^{(\mathrm{a})}$ & 197 & 49,0 & $20,0[5,0-25,0]$ & $\chi^{2}=10,924$ & $15,0[4,0-20,0]$ & $\chi^{2}=4,782$ \\
\hline $6-10^{(\mathrm{b})}$ & 106 & 26,4 & $18,0[5,0-25,0]$ & $\mathrm{p}=0,004$ & $16,0[4,0-20,0]$ & $\mathrm{p}=0,092$ \\
\hline$\geq 11^{\text {(c) }}$ & 99 & 24,6 & $19,0[8,0-25,0]$ & {$[\mathrm{a}-\mathrm{b}]$} & $14,0[4,0-20,0]$ & \\
\hline \multicolumn{7}{|l|}{ Çalıştığı Klinik } \\
\hline Dahiliye Kliğini (a) & 157 & 39,1 & $19,0[7,0-25,0]$ & $\chi^{2}=5,151$ & $15,0[4,0-20,0]$ & $\chi^{2}=11,730$ \\
\hline Cerrahi Kliniğ $i^{(b)}$ & 145 & 36,1 & $19,0[5,0-25,0]$ & $\mathrm{p}=0,076$ & $16,0[4,0-20,0]$ & $\mathrm{p}=0,003$ \\
\hline Yoğun Bakım ${ }^{(\mathrm{c})}$ & 100 & 24,9 & $18,5[5,0-25,0]$ & & $14,0[4,0-20,0]$ & {$[b-a, c]$} \\
\hline \multicolumn{7}{|l|}{$\begin{array}{l}\text { Çalıştığı Klini } \\
\text { ğini Kendi Seçme }\end{array}$} \\
\hline Durumu & 117 & 29,1 & $19,0[7,0-25,0]$ & $Z=-0,659$ & $16,0[4,0-20,0]$ & $Z=-0,487$ \\
\hline Evet & 285 & 70,1 & $19,0[5,0-25,0]$ & $\mathrm{p}=0,510$ & $15,0[4,0-20,0]$ & $\mathrm{p}=0,626$ \\
\hline \multicolumn{7}{|l|}{ Hayır } \\
\hline \multicolumn{7}{|l|}{ Çalıştığı Klinikten } \\
\hline \multicolumn{7}{|l|}{ Memnun Olma } \\
\hline Durumu & 214 & 53,2 & $19,16 \pm 4,34$ & $\mathrm{~F}=80,98$ & $16,0[4,0-20,0]$ & $\chi^{2}=5,430$ \\
\hline Memnun $^{(a)}$ & 151 & 37,6 & $17,39 \pm 4,41$ & $p=0,000$ & $15,0[4,0-20,0]$ & $\mathrm{p}=0,066$ \\
\hline Kismen Memnun $^{(b)}$ & 37 & 9,2 & $17,37 \pm 4,62$ & {$[a-b]$} & $17,0[4,0-20,0]$ & \\
\hline \multicolumn{7}{|l|}{ Memnun Değil ${ }^{(\mathrm{c})}$} \\
\hline Çalıştığı Kliniği & & & & & & $\mathrm{Z}=3,060$ \\
\hline Değiştirme Düşüncesi & & & & $Z=3,803$ & & $\mathrm{p}=0,002$ \\
\hline Var & 138 & 34,3 & $17,0[5,0-25,0]$ & $\mathrm{p}=\mathbf{0 , 0 0 0}$ & $15,0[4,0-20,0]$ & \\
\hline Yok & 264 & 65,7 & $20,0[5,0-25,0]$ & & $16,0[4,0-20,0]$ & \\
\hline
\end{tabular}

Araştırmaya konu olan hemşirelerin cinsiyet, medeni durum, çalışma yılı, çalışı ı̆ı kliniği kendini seçme ve çalıştığı klinikten memnun olma durumuna göre Kişi Örgüt Uyumu Ölçeği puanları acısından anlamlı bir farklılık yoktur(p>0,05). Hemşirelerin yaşlarına göre Kişi Örgüt Uyumu Ölçeği puanları acısından anlamlı bir farklılık bulunmuştur $\left(\chi^{2}=7,794 ; \mathrm{p}=0,024\right)$. Yaş grubu 18 -25 ve 36-45 y1l arası olan hemşirelerin Kişi Örgüt Uyumu Ölçeği puanları, yaş grubu 26-35 yıl arası olan hemşirelere göre istatistiksel olarak anlamlı düzeyde daha yüksektir. Çalışmaya katılan hemşirelerin eğitim düzeylerine göre Kişi Örgüt Uyumu Ölçeği puanları acısından anlamlı bir farklılık bulunmuştur $\left(\chi^{2}=6,354 ; \mathrm{p}=0,042\right)$. Eğitim düzeyi lise olan 
hemşirelerin Kişi Örgüt Uyumu Ölçeği puanları, eğitim düzeyi lisans olan hemşirelere göre istatistiksel olarak anlamlı düzeyde daha yüksek olduğu bulunmuştur. Hemşirelerin çalıştığ 1 kliniğe göre Kişi Örgüt Uyumu Ölçeği puanları açısından anlamlı bir farklılık bulunmuştur $\left(\chi^{2}=11,730 ; p=0,003\right)$.Dahiliye ve cerrahi kliniğinde çalışan hemşirelerin Kişi Örgüt Uyumu Ölçeği puanları, yoğun bakımda çalışan hemşirelere göre istatistiksel olarak anlamlı düzeyde daha yüksek olduğu tespit edilmiştir.Çalışmaya katılan hemşirelerin, çalıştığı kliniğini değiştirme düşüncesine sahip olma durumuna göre Kişi Örgüt Uyumu Ölçeği puanları açısından istatistiksel olarak anlamlı farklılık saptanmıştır $(\mathrm{Z}=3,060 ; \mathrm{p}=0.002)$. Çalıştığı kliniği değiştirmeyi düşünmeyen hemşirelerin Kişi Örgüt Uyumu Ölçeği puanları, çalıştı̆̆ kliniği değiştirmeyi düşünen hemşirelere göre istatistiksel olarak anlamlı düzeyde daha yüksektir(Tablo 1).

Hemşirelerin Yöneticiye Güven Ölçeğinden aldığı puanlar ile Kişi Örgüt Uyumu Ölçeğinden aldığı puanlar arasında pozitif yönde, zayıf derecede ve istatistiksel olarak anlamlı ilişki tespit edilmiştir $(r=0.482 ; \mathrm{p}<0.000)$ (Tablo 2).

Tablo 2. Hemşirelerin Yöneticiye Güven Ölçeği ve Kişi Örgüt Uyumu Ölçeği Puanları iliş̧isi

\begin{tabular}{lcc}
\hline Korelasyon* & Kişi Örgüt Uyumu Ölçeği & Korelasyon* \\
& $\mathbf{r}$ & 0,482 \\
& $\mathbf{p}$ & $<0.000$ \\
\hline *Normal dağılıma sahip olmayan iki nicel değişkenin birbiriyle ilişkilerinin incelenmesinde "Spearman" korelasyon katsayısı \\
kullanılmıștır.
\end{tabular}

Günümüz dünyasında örgütlerin değişime ayak uydurabilmesi ve başarılı olmasında çevresel, yönetsel ve yapısal faktörler rol oynamaktadır. Yönetsel faktörler başarı ve başarısızlığın ana sebebini oluşturmaktadır. Kararlı, cesaretli ve hızlı liderlik anlayışı örgütün dış koşullarla baş etmesini sağlayacaktır (Artan ve ark., 1997). Günümüz dünyasında güce dayalı ilişkiden çok güvene dayalı ilişki önem kazanmıştır. Çalışanlarının iş doyumlarını arttırmak, kişi örgüt uyumunu sağlamak ve dolayısıyla başarıyı yakalamak için yöneticilerin üzerlerine düşen sorumluluğu yerine getirmeleri beklenir (Reynolds, 1997).

Araştırmamamıza katılan hemşirelerin yöneticiye güven ölçeğinden aldıkları puan ortalaması 18.33 .4 .47 olarak saptanmıştır. Bu bulguya göre hemşirelerin orta düzeyde bir güven duygusuna sahiptir. Güvenilen liderler; açık fikirli, astlarını dinleme becerisine sahip, kriz sürecinde soğukkanlılığını koruyabilen, öz disiplin uygulayabilen ve duygularının yönetiminde öz denetim ve kişilerdir. Bu özelliklere sahip yöneticiler ve çalışanlar arasında karşıllklı saygı ve güven ortamı oluşur (Syed, 2013). Etkin biçimde iletişim kuran bir yönetici çalışanların örgütün amaçları doğrultusunda davranmalarını kolaylıkla sağlar. Örgütlerde bireyler arası güven; astın yöneticiye güveni, yöneticinin asta güveni, çalışanlar arası güven, departmanlar ve gruplar arası güven ilişkilerini içermektedir (Börü vd. 2007). Örgüte güven daha çok algılanan örgütsel destek ve örgütsel adalet ile ilişkilidir. Yöneticiye güven amirin yetenek, yardımseverlik ve dürüstlügü ile ilişkidir. Çalışanın yöneticisini örgütün temsilcisi gibi görmesi, bu güveni örgüte yaymasına neden olabilir (Tan ve Tan, 2000). Güvenin, iş doyumunu yükseltirken işlem maliyetlerini düşüreceği beklenmektedir. (Cho ve Poister, 2014)

Çalışanlar yöneticileri ile kurdukları iletişimin adil, güvenli, adil, şeffaf olduğuna inanır ve bu iletişimin etkinliğini içselleştirirlerse değişime ayak uydurmaları ve kişi örgüt uyumunun sağlanması kolaylaşacaktır. İşten çıkarmalar nedeniyle çalışan yöneticisine, çalışma arkadaşlarına ve yönetime güvensizlik duymaktadır. Yönetime güvensizlik yönetim ve çalışanları karşı karşıya getirmekte ve çalışanları her anlamda olumsuz etkilemektedir. Bu nedenle çalışanların güvenini sağlamak yöneticiler için daha da önemli hale gelmiştir.

Araştırmamıza katılan hemşirelerin kişi örgüt uyumu ölçeğinden aldıkları puan ortalaması 14.02 \pm .3 .86 olarak saptanmıştır. Buna göre hemşirelerin örgüt uyumu orta düzeydedir. Kişi-örgüt uyumu; değerler, inançlar ve amaçlar açısından kişi ve örgüt arasındaki uyumdur (Andrews ve ark., 2011). Kişi-örgüt uyumu hem çalışan hem de kurumlar için oldukça önemlidir. 
$\mathrm{Bu}$ uyumun sağlanması örgüt ve çalışan tarafindan beklentilerin karşılanmasında ve örgütün istenilen başarıya ulaşmasında önemlidir. Kişisel ve örgütsel değer, hedef ve ihtiyaçların uyumu olan kişi -örgüt uyumunun sağlanması için "Örgüt liderleri ile astlarının hedeflerinin uyumunu sağlamak.", "Kişisel tercih veya ihtiyaçları örgüt yapısı ve sistemi ile uyumlu hâle getirmek" ve "Şahısların kişiliği ile örgütün kişiliği olarak tanımlanan örgüt iklimi arasında uyum sağlanmalıdır.

Birey ile çalıştığı örgüt ve yaptığı iş arasındaki uyum seviyesi arttıkça iş tatminleri, örgütsel aidiyetleri, üretkenlikleri artacak ve örgütte devam etmeye daha istekli hale geleceklerdir. Bu çalışmanın ortaya koyduğu sonuçlara göre bireyin kişiliği, değerleri, amaçları ve tutumları ile çalıştığı örgütün kültürü, değerleri, amaçları ve normları arasındaki uyum ve aynı şekilde bireyin yaptığ 1 işin kişiye sundukları ya da gerektirdikleri ile o işi yapanın beklentileri ya da becerileri arasındaki uyum seviyesi arttıkça kişinin o örgüte olan bağlılığ 1 , sergilediği çalışma performansı ve işinden duyduğu tatmin düzeyi artacak; işi ile ilgili hissettiği stres seviyesi de azalacaktır. Kişi ile örgüt ve yaptığı iş arasındaki uyum seviyesi arttıkça çalışların iş doyumları, performansları, üretkenlikleri artmakta ve örgütte devam etmeye daha istekli olmaktadırlar. Kişiörgüt uyumunun sağlanmadığında; bireyde uyumsuzluk, endişe ve stres yaşanmaktadır (İplik ve ark.,, 2011). Literatürde yapılan çalışmalarda; birey-örgüt uyumunun iş doyumu, iş performans1, örgütsel aidiyet, örgütsel vatandaşlık üzerinde pozitif etkisi, işten ayrılma niyeti ve iş devir hızı ile negatif etkisi saptanmıştır (Sekiguchi, 2004; İplik ve ark., 2011; Behery, 2009; Li ve Hung, 2010; Yang ve Mossholder, 2010; Akbaş, 2011; Andrews ve ark., 2011; Gibson ve Petrosko, 2014).

Kişi- örgüt uyumunun sağlanmasında çalışan açısından önemli olan faktörlerden birisi de yöneticiye duyulan güvendir. Araştırmamamıza katılan hemşirelerin yöneticiye güven ile kişi örgüt uyumu arasında anlamlı bir ilişki bulunmuştur. Yöneticiler, örgüt ve astlar arasında resmi bir bağlantıdır. Amirler örgütsel politika ve hedeflerin astlara iletilmesinden doğrudan sorumludurlar. Bir çalışan amiri ile etkileşiminden çıkarımlar yaparak örgüte güvenle ilgili yargilarda bulunabilir. Çalışanlar amire güvenirse, amiri örgütün temsilcisi olarak algıladıklarında güveni tüm örgüte genelleyebilir. (Tan ve Tan, 2000). Literatürde yapılan çalışmalarda yöneticiye güvenin, takım çalışmasını ve örgütsel performansı artıracağı ifade edilmektedir (Cho\&Poister, 2014). Sağlık alanında hizmet veren hemşirelerin yönetici hemşirelerine güvenmesi etkin bir ekip çalışmasında önemlidir. Etkin bir ekip çalışmasının; hastanın bakımı ve tedavisi sürecinde etkin problem çözme ve karar vermeyi ve bakım verile bireylere ilişkin daha çok veri elde etmeyi sağladığı bilinmektedir. Ayrıca; hastayı öz bakımıyla ilgili kararlarda güçlendirdiği, bir probleme daha fazla alternatif yaklaşım getirdiği, bilgi ve yeteneğe dayalı karmaşık problemleri çözme olanağını artırdığı, hasta güvenliğini sağladığı ve maliyeti düşürdüğü bilinmektedir (Türe Yılmaz ve Yıldırım, 2018).

Yöneticiye duyulan güven bireysel ve örgütsel olumlu çıktılara yol açmaktadır (Tan \& Tan, 2000: 244). Diğer taraftan bu güven, çalışanların örgütsel kuralara uymalarına ve örgütsel değişimin gerçekleşmesine yardımcı olacak, performanslarını doğrudan etkileyecektir (Arslantaş\& Dursun, 2008). Birçok çalışmada güven ile örgütsel performans ve iş tatmini arasında olumlu iliş̧ki tespit edilmiştir (Davis vd., 2000; Tan ve Tan, 2000; Yang ve Mossholder, 2010). Gibson ve Petrosko (2014) çalışmalarında, lidere olan güvenin yüksek olması durumunda iş tatmininin artıracağının tespiti sonrasında, güven inşa etme konusunda yanlışa düşen liderin iş tatminde olumsuzluklarla karşılaşacağını ifade etmiştir (Gibson\&Petrosko, 2014).

Araştırmamıza katılan hemşirelerin; çalışma yılı 1-5 yıl arası olan hemşirelerin, çalışma yılı 6-10 yıl arası olan hemşirelere göre yöneticilere güveni daha yüksektir. Toplam çalışma süresi ve yönetici ile birlikte geçirilen sürenin anlamlı farklar gösterdiği görülmüştür. Bu durum yeni işe başlayan hemşirelerin daha hevesli olmasına bağlanabilir. Çalıştığ klinikten memnun olan hemşirelerin, çalıştığı klinikten kısmen memnun olan hemşirelere göre yöneticilere güveni daha yüksektir. Bu durum çalıştığı klinikten memnun olan hemşirelerin yöneticiye güvenlerinin daha fazla olmasına bağlanabilir. Literatürde hemşire-hemşire iletişimi ve iş birliğinin sağlanması ile 
ilgili yapılan çalışmalarda ise; tıbbi hataların azaldığı, hasta güvenliği sağladığg ve bakım kalitesinin arttı̆̆1 saptanmıştır (Dougherty ve Larson, 2010; Tanaka ve ark., 2010).

Çalıştığ1 kliniği değiştirmeyi düşünmeyen hemşirelerin, çalıştığ1 kliniği değiştirmeyi düşünen hemşirelere göre yöneticilere güveni daha yüksektir. Aynı şekilde; Çalıştığı kliniği değiştirmeyi düşünmeyen hemşirelerin, çalıştı̆̆ kliniği değiştirmeyi düşünen hemşirelere göre kişi örgüt uyumu daha yüksektir. Bu durum çalıştığı klinikten memnun olan hemşirelerin yöneticileri ile iletişimlerinin ve etkileşimlerinin daha fazla ile değerlendirilebilir. Literatürde yapılan çalışmalarda sağlık profesyonelleri arasında sağlanan iş birliği ve güvenin; iş doyumu ve mesleki otonomiyi arttırdığı, işten ayrılma devir hızını azalttığı, hasta yararına iş birliği ile karar verme sürecini sağladığı saptanmıştır (Anthoine ve ark., 2014). Yaş grubu 18 -25 ve 36-45 yıl arası olan hemşirelerin, yaş grubu 26- 35 yıl olan hemşirelere göre kişi örgüt uyumu daha yüksektir. İş hayatında geçirilen süre uzadıkça yöneticiye güvenin zorlaşması ile değerlendirilebilir. Dahiliye ve cerrahi kliniğinde çalışan hemşirelerin kişi örgüt uyumu yoğun bakımda çalışan hemşirelere göre daha yüksektir. Yoğun bakım ortamında çalışmanın hemşireler için daha yoğun, stresli ve yorucu olması hemşirelerin uyumunu zorlaştırdığı düşünülmektedir.

Çalışmamızda yöneticiye duyulan güven ile kişi örgüt uyumu arasında pozitif yönde, istatistiksel olarak anlamlı ilişki tespit edilmiştir $(\mathrm{r}=0.482 ; \mathrm{p}<0.000)$ (Tablo 2). Besen ve Aktaş (2016) çalışmasında; yöneticiye duyulan güven ile kişi örgüt uyumu arasında pozitif korelâsyon içinde olduğu tespit edilmiştir. Yapılan araştırmalar örgütteki güvenin, organizasyon performansını olumlu yönde etkilediğini göstermektedir (Wang ve ark., 2008; Shamir ve Lapidot, 2003; Tan ve Lim, 2009). Aynı zamanda, örgüt içerisindeki güven ortamı, örgütteki kişi ve örgüt arasında da uyumlu çalışma ortamı sağladığından (Garcia ve ark., 2008) bu durum örgüt performansı üzerine olumlu olarak yansımaktadır (Turunç ve Çelik, 2012). Yöneticiye duyulan güven ile kişi örgüt uyumu üzerindeki pozitif etkisi olduğu ve çalışanların; iş doyumunu, iş performansını arttıracağı düşünülmektedir. Ayrıca, işten ayrılma niyetinde ve işte yalnızlıkta azalmayı sağlayacaktır. Hemşirelerde yöneticiye güven, hasta bakımın kalitesinde artmayı mükemmelliği ve hemşirelerin işten ayrılma devir hızında azalmayı sağlar (Bobbio, 2012). Literatürde yapılan çalışmalar incelendiğinde; bakım kalitesinin artmasıyla ilişkili olarak hasta memnuniyetinin sağlanmasın da önemli bir yere sahiptir ( Kroposki ve Alexander, 2006).

\section{Sonuç ve Öneriler}

Çalışmamızda yöneticiye duyulan güven ile kişi örgüt uyumu arasında anlamlı ilişki bulunmuştur. Bu konuyla ilgili daha kapsamlı çalışmaların yapılması önerilebilir.

\section{Kaynakça}

Akbaş, T. T. (2011). Algılanan Kişi-Örgüt Uyumunun Örgütsel Vatandaşlık Davranışları Üzerindeki Etkisi: Görgül Bir Araştırma. Yönetim Bilimleri Dergisi, 9(1):57-81.

Akkoç, İ., Çalışkan, A., \& Turunç, Ö. (2012). Örgütlerde Gelişim Kültürü ve Algılanan Örgütsel Desteğin İş Tatmini ve İş Performansına Etkisi: Güvenin Aracılık Rolü, Yönetim ve Ekonomi: Celal Bayar Üniversitesi İktisadi ve İdari Bilimler Fakültesi Dergisi, 19(1): 105-135.

Andrews, Baker ve Hunt (2011). Valuesandperson-organization Fit: Does Moral Intensity Strengthenoutcomes? Leadership\&Organization Development Journal, 32(1): 5-19.

Anthoine, E., Delmas, C., Coutherut, J., \&Moret, L. (2014). Development and Psychometric Testing of a Scale Assessing the Sharing of Medical Information and Interprofessional Communication: the CSI scale, BMC Health Services Research, 14(1):126.

Arbak, Y. ve T. Yeşilada (2003). "Örgüt Kişi Uyumu ve Örgütsel Çekicilik: Hangi Kişiler Ne Tür Örgütleri Daha Çekici Bulur?", Journal Of İstanbul Kültür Üniversitesi, 1(4): 23-37.

Arı, G. S. (2003). Yöneticiye Duyulan Güven Örgütsel Bağlılığı Artırır mı? Gazi Üniversitesi Ticaret ve Turizm Ĕ̌itim Fakültesi Dergisi, 2(2): 17-36. 
Arslantaş, C. C., \& Pekdemir, I. (2007). Dönüşümcü Liderlik, Örgütsel Vatandaşlık Davranış1 ve Örgütsel Adalet Arasındaki İlişkileri Belirlemeye Yönelik Görgül Bir Araştırma, Anadolu Üniversitesi Sosyal Bilimler Dergisi, (1):261- 286.

Artan, E. İ.: (1997). Endüstri ve Örgüt Psikolojisi, (Editör: Suna Tevruz), İçinde: Örgütsel Değişim ve Gelişme, 2. Baskı, Türk Psikologlar Derneği-Kalite Derneği Yayını, Ankara:103117.

Ashforth, B. E., Sluss, D. M., \&Saks, A. M. (2007). Socialization tactics, Proactive behavior, and newcomer learning: Integrating Socialization Models, Journal of Vocational Behavior, 70(3): 447-462.

Bauer, T. N., Bodner, T., Erdogan, B., Truxillo, D. M., \&Tucker, J. S. (2007). Newcomer Adjustment During Organizational Socialization: A Meta-Analyticreview of Antecedents, Outcomes, and Methods. Journal of Applied Psychology, 92(3): 707-721.

Behery, M. H. (2009). Person/Organizationjob-Fitting And Affective Commitment To the Organization: Perspectivesfromthe UAE. Cross Cultural Management: An International Journal 16(2):179-19.

Besen, E., \& Aktaş, H. (2016) Birey- Örgüt Uyumu ve Yöneticiye Duyulan Güven ile Lider-Üye Etkileşimi Bağlamında Bursa'da Otomotiv Sektörü Çalışanları Üzerinde Bir Araştırma YÖNETIM: İstanbul Üniversitesi Işletme İktisadı Enstitüsü Dergisi, 27(81): 1-19.

Bobbio, A., Bellan, M., \&Manganelli, A. M. (2012). Empoweringleadership, Perceived Organizational support, Trust, And job burnout for nurses: A Study in an Italian General Hospital. Healthcare Management Review, 37(1), 77-87.

Börü, D., İslamoğlu, G., \& Birsel, M. (2007). Güven: Bir Anket Geliştirme Çalışması. Öneri Dergisi, 27(7), 49-59.

Cho, Y. J., \&Poister, T. H. (2014). Managerial Practices, Trust in Leadership, Andperformance: Case of the Georgia Department of Transportation, Public Personnel Management, 43(2), 179-196.

Cook, J. ve T. Wall (1980). New Work Attitude Measures of Trust, Organizational Commitment and Personal Need Non-fulfilment. Journal of Occupational Psychology, 53(1): 39-52.

Çokluk Bökeoğlu, Ö. ve Yılmaz, K. (2008) İlköğretim Okullarında Örgütsel Güven Hakkında Öğretmen Görüşleri, Kuram ve Uygulamada Eğitim Yönetimi, 14(54):211- 233.

Demircan, N., \& Ceylan, A. (2003). Örgütsel Güven Kavramı: Nedenleri ve Sonuçları, Yönetim ve Ekonomi: Celal Bayar Üniversitesi İktisadi ve İdari Bilimler Fakültesi Dergisi, 10(2):139150.

Dougherty, M. B., \&Larson, E. L. (2010). The Nurse-nurse Collaboration Scale, Journal of Nursing Administration, 40(1): 17-25.

Driscoll, J. W. (1978). Trust and Participation in Organizational Decision Making as Predictors of Satisfaction,Academy of Management Journal, 21(1): 44-56.

Garcia, Nuria, Sanzo M. Jose', TrespalaciosJuan A. (2008). New Product Internal Performance and Market Performance: Evidence from Spanish Firms Regarding the Role of Trust, Interfunctional Integration, and Innovation Type, Technovation, (28): 713-725.

Gerstner, C. R. ve D. V. Day (1997). Meta-Analytic Review of Leader-member Exchange Theory: Correlates and Constructissues, Journal of Applied Psychology, 82(6): 827-844.

Gibson, D., \&Petrosko, J. (2014). Trust in Leaderandits Effect on Job Satisfaction and in Tent to Leave in a Healthcaresetting, New Horizons in Adult Educationand Human Resource Development, 26(3): 3-19. 
İplik, F. N., Kılıç, K. C. ve Yalçın, A. (2011). The Simultaneous Effects of Person-organization and Person-job Fit on Turkish Hotel managers, International Journal of ContemporaryHospitality Management, 23(5): 644-661.

Kristof, A. L. (1996). Person-organization fit: An integrative review of its conceptualizations, measurement, and implications, Personnel psychology, 49(1): 1-49.

Koç, H., \& Yazıcıoğlu, İ. (2011). Yöneticiye Duyulan Güven ile İş Tatmini Arasındaki İlişki: Kamu ve Özel Sektör Karşılaştırması, Doğuş Üniversitesi Dergisi, 12(1):46-57.

Kroposki, M. Alexander, JW. (2006) Correlation Among Client Satisfaction, Nursing Perception of Outcomes, and Organizational Variables, Home Healthcare Nurse (24): 2, 87-94.

Lewin, K. (1935). A Dynamic Theory of Personality: Selected Papers of Kurt Lewin. New York: McGraw-Hill.

Li, C. \& Hung, C. (2010). An Examination of the Mediating Role of Person-job Fit in Relations between İnformation Literacy And Work Outcomes. Journal of Workplace Learning, 22(5): 306-318.

Mayer, R. C., Davis, J. H., \& Schoorman, F. D. (1995). An Integrative Model of Organizational Trust. Academy of Management Review, 20(3): 709-734.

McAllister, D. J. (1995). Affect-and Cognition-Based Trust as Foundations for Interpersonal Cooperation in Organizations. Academy of Management Journal, 38(1): 24-59.

Mishra, A. K. (1996). Organizational Responses to Crisis: The Centrality of Trust. içinde Roderick M. Kramer ve Tom R. Tyler (ed.), Trust in organizations: Frontiers of the or and Research .London: SAGE Publications.

Murray, H. A. (1951). Toward a Classification of Interaction. In T. Parsons ve E. A. Shils (Eds.). Toward a General Theory of Action: 434-464. Cambridge, MA: Harvard University Press.

Reynolds, L.: (1997), The Trust Effect, Creatingthe High Trust, High Performance Organization, Nicholas Brealey Publishing, London.

Sekiguchi, T. (2004). Person-organization Fit and Person-job Fit in Employee Selection: A Review of the Literature, Osaka Keidai Ronshu, 54(6):179-196.

Shamir, B. ve Y. Lapidot (2003). Trust in Organizational Superiors: Systematic and Collective Considerations, Organization Studies, 24(3): 463-491.

Syed, A.:(2013). Building Bridges Between Quality and Leadership, Quality Leadership is No Accident: Universal Steps to Develop the Extraordinary Leader Within You, içinde Bölüm 4, Leadership is an Art; Management is a Science, 27-30, Bölüm 5, TheLeadership Model, 3133.

Tan, H. H., \& Tan, C. S. (2000). Toward the Differentiation of Trust in Supervisor and trust in Organization, Genetic, Social, and General Psychology Monographs, 126 (2): 241.

Tan, H. H., Lim, A.K.H. (2009). Trust in Coworkers and Trust in Organizations, The Journal of Psychology, 143(1),45-66.

Tanaka, K., Takahashi, M., Hiro, H., Kakinuma, M., Tanaka, M., Kamata, N., \&Miyaoka, H. (2010). Differences in Medicalerror Risk among Nurses Working Two-and Three-shift Systems at Teaching Hospitals: A Six-Month Prospective Study, Industrial Health, 48(3), :357-364.

Thomas, G. F., Zolin, R., \&Hartman, J. L. (2009). Thecentral Role of Communication in Developing Trust and it seffect on Employee İnvolvement, The Journal of Business Communication (1973), 46(3): 287-310. 
Turunç, Ö., \& Çelik, M. (2012). İş Tatmini-Kişi Örgüt Uyumu ve Amire Güven-Kişi-Örgüt Uyumu İlişkisinde Dağıtım Adaletinin Düzenleyici Rolü, ISGUC The Journal of Industrial Relations and Human Resources, 14(2): 57-78.

Yahyagil, M. Y. (2005). Birey ve Organizasyon Uyumu ve Çalışanların İş Tutumlarına Etkisi, Marmara Üniversitesi Öneri Dergisi, (24): 137-149.

Yang, J., \& Mossholder, K. W. (2010). Examining the Effects of Trust in Leaders: A Bases-andFoci Approach, The Leadership Quarterly, 21(1): 50-63.

Yeşiltaş, M., \& Keleş, Y. (2009). İş Görenlerin Eğitim Düzeyleri ve Örgütsel Vatandaşlık Davranışları Arasındaki İlişkinin İncelenmesine Yönelik Bir Araştırma, Gazi Üniversitesi Íktisadi ve İdari Bilimler Fakültesi Dergisi, 11(2): 17-40.

Wang, I-M., Shieh C.-J., Wang F.-Ji. (2008). Effect Of Human Capital Investment on Organizational Performance, Social Behavior and Personality, 36 (8):1011- 1022. 